\title{
Clarifying Key Cellulase Component Cooperated With Lactic Acid Bacteria for Alfalfa Lignocellulose Degradation to Improve Lactic Acid Production
}

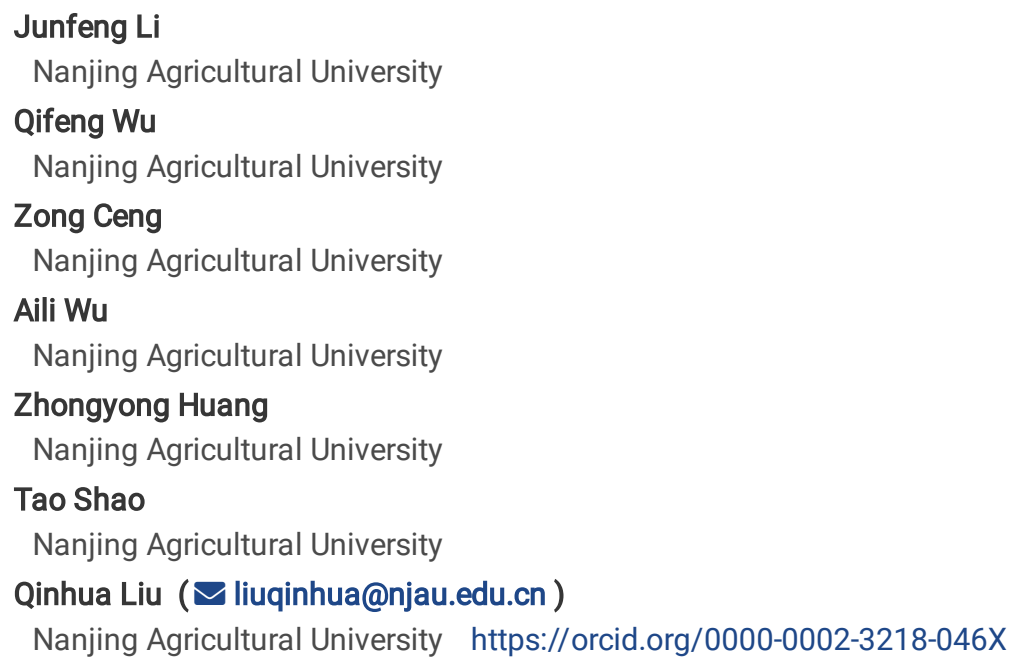

\section{Research Article}

Keywords: Lignocellulose, Degradation, Sugar, Lactic acid

Posted Date: October 29th, 2021

DOl: https://doi.org/10.21203/rs.3.rs-1011810/v1

License: @ (1) This work is licensed under a Creative Commons Attribution 4.0 International License. Read Full License 


\section{Abstract}

Clarifying key cellulase component that played synergistic roles with lactic acid bacteria (LAB) in fermenting alfalfa lignocellulose into lactic acid (LA) is valuable in low-temperature seasons. Last cut and low dry matter (DM) alfalfa was ensiled by 9 treatments, combinations of cellulase component genes engineered Lactoc. lactis subsp. lactis MG1363 strains (HT2, HT3, HT4, HT5, E1C1, E1B1, and C1B1, separately containing $\mathrm{bg} / 1, \mathrm{cbh} 2$, and eg/3 gene were mixed at 1:1:1, 2:1:1, 1:2:1, 1:1:2, 1:1:0, 1:0:1, and 0:1:1), cellulase (EN), and a combination of Lactobacillus plantarum and cellulase (LPEN), and without treatments, as the control, with 4 replicates each. After anaerobic preservation in a silo from late fall through winter $\left(3-20^{\circ} \mathrm{C}\right)$ for $140 \mathrm{~d}$, the ensiled alfalfa was sampled and analysed. EN degraded lignocellulose best but the $\mathrm{pH}$ was the key limiting factor for lignocellulose saccharification of commercial EN in the simultaneous saccharification and fermentation of LPEN. The optimal combination HT4 caused the fewest disaccharide $(1.02 \mathrm{~g} / \mathrm{kg} \mathrm{DM})$ and the highest conversion of water-soluble carbohydrates (WSC) to LA (170\%) and increased LA content to $80.0 \mathrm{~g} / \mathrm{kg} \mathrm{DM}$ maximally since cellobiohydrolase better cooperated with Lactoc. lactis host to ferment lignocellulose into LA than endoglucanase and $\beta$-glucosidase. Therefore, strong LA production was approached in HT4 by clarifying key cellulase component played synergistic roles with Lactoc. lactis host. This study could benefit the development of LA production in fermenting lignocellulosic biomass.

\section{Introduction}

The grass is widely distributed renewable lignocellulosic biomass in the world. The lignocellulose is the natural polymers. In grass, lignocellulose mainly contain 29-35\% cellulose, 26-32\% hemicellulose, and 16-21\% lignin (Galkin and Samec 2016). The conversion of lignocellulosic polymers to versatile platform chemicals by anaerobic fermentation is a reliable way to avoid resource competition between food and chemical industries (Liu et al. 2020). Lactic acid (LA) is a versatile chemical and has been widely applied in various industries including food, leather tanning, cosmetics, and pharmaceuticals (Martinez et al. 2013). Approximately $90 \%$ of global LA is produced via microbial fermentation (Haag et al. 2016; Alexandri et al. 2019), which requires low production temperature and has low energy requirements and high purity (Wee et al. 2006). Ensiling is an anaerobic fermentation process, which naturally depends on the epiphytic lactic acid bacteria (LAB) fermenting water-soluble carbohydrates (WSC) into LA to decrease pH. Consequently, LA-dominated plants can be well conserved as feedstock (McDonald 1981). In recent years, ensiling has been defined as an eco-friendly, green, and sustainable lignocellulose degradation technique for producing LA from biomass (Haag et al. 2016; Bichot et al. 2018).

To increase the LA in ensiled grass, homo-fermentative LAB, such as Lactobacillus plantarum and Lactococcus lactis, produce more LA from glucose than hetero-fermentative LAB and are employed in the ensiling yield. Kung (2015) reported that homo-fermentative LAB might have produced more LA during ensiling lignocellulosic biomass compared with the control, but the degree of preventing harmful Clostridial fermentation depended on the circumstances, e.g., material and temperature. Alfalfa, containing high protein content, is widely used as ruminant feed and is also a good candidate feedstock for LA production. However, its low contents of WSC and dry matter (DM) and high buffering capacity (BC) lead to difficultly control undesired Clostridial fermentation (Mcdonald et al. 1991). In the cold seasons, weak LA fermentation often occurs (Cao et al. 2011; Wang et al. 2017). Therefore, how to use homo-fermentative LAB maximally to increase LA production and restrain undesired fermentation in ensiling high moisture alfalfa is an interesting research direction.

Most homo-fermentative $L A B$ is not able to secrete the enzymes to degrade lignocellulose, $L A$ production cannot meet the requirement of the industry. Although our group isolated some cellulolytic LAB from the rumen, it did not improve the conversion of WSC into LA (CWL) relative to adding exogenous cellulase in ensiled alfalfa due to the poor ability to produce LA (Liu et al. 2020). Li et al. (2018a) found that cellulolytic LAB derived from rumen degraded the lignocellulose of Pennisetum sinese and increased the LA content compared with the control, but stronger LA fermentation and CWL were exhibited by Lactobacillus plantarum combined with them. Cellulase consists of endoglucanase (EG), cellobiohydrolase (CBH), and $\beta$-glucosidase (BG) and hydrolyzes the $\beta-1,4-\mathrm{D}$-glycosidic bonds of cellulose. The cellulose is degraded into monosaccharides successfully and completely, which depended on the composing proportion of cellulase. Du et al. (2018) reported that the difference in the composition of cellulase mixture influenced its applicability in different pretreated materials. Optimization of the proportions of individual component in cellulase mixture has been highlighted the importance of lignocellulose hydrolysis. On the other hand, CBH and BG are sensitive to cellobiose and glucose, respectively (Riou et al. 1998; DeCker et al. 2001; Teugjas and Väljamäe 2013). The BG often plays a rate-limiting role in cellulose degradation. To delete this limitation, simultaneous saccharification and fermentation using combination of cellulase and $L A B$ was applied to ensiling grass. However, some previous studies have described negative effects of the combined treatment of cellulase and LAB on ensiling alfalfa, such as ineffectiveness on decreasing DM loss, neutral detergent fiber (NDF) and acid detergent fiber (ADF), and increasing LA content compared with the control (Kozelov et al. 2007; Lynch et al. 2014). The proposed explanation is that some cellulases cannot degrade lignocellulose of alfalfa (Lynch et al. 2014), some lignocellulose degradation products of cellulase (high-molecularweight oligosaccharides) cannot be fermented by LAB (Stokes and Chen 1994; Tarraran and Mazzoli 2018), or the timeliness of cellulase and LAB was different (Liu et al. 2019). However, the bottleneck of lignocellulose degradation was that little known about which cellulase 
component played synergistic roles with LAB in fermenting alfalfa lignocellulose into lactic acid. Therefore, providing the above information can benefit the development of LA production in ensiling lignocellulosic biomass.

Recently, our group constructed engineered Lactoc. lactis subsp. lactis MG1363 (MG1363) strains separately containing the bg/1, cbh2, and eg/3 gene of Trichoderma reesei. The combination proportion of engineered MG1363 strains (HT2) containing bg/1, cbh2, and eg/3 genes at 1:1:1 could secrete cellulase (236 mU/ml FPase activity) (Liu et al. 2019). We hypnotized that optimizing the combinations of engineered MG1363 strains could clarify key cellulase component playing synergistic roles with LAB in fermenting alfalfa lignocellulose to improve LA production. To test the hypothesis, the lignocellulose degradation, sugar profile, fermentation characteristics, and CWL of high-moisture alfalfa was investigated after ensiling in low-temperature seasons for $140 \mathrm{~d}$, using commercial $T$. reesei cellulase (EN), and the combination of Lactob. plantarum and commercial cellulase (LPEN) as parallel treatments for the 7 combinations of engineered MG1363 strains treatments.

\section{Materials And Methods}

\section{LAB strains, material, and ensiling treatments}

The engineered strains of MG1363 containing $b g / 1, c b h 2$, and eg/3 gene of $T$. reesei were constructed in our lab by Liu et al. (2019). After culturing in $\mathrm{GM} 17$ broth medium at $30^{\circ} \mathrm{C}$ for $30 \mathrm{~h}$, engineered strains containing $b g / 1, c b h 2$, and eg/3 gene were mixed at 1:1:1, 2:1:1, 1:2:1, 1:1:2, 1:1:0, 1:0:1, and 0:1:1 and were named HT2, HT3, HT4, HT5, E1C1, E1B1, and C1B1 separately. The LPEN was a combination of Lactob. lantarum and commercial cellulase. Lactob. plantarum was isolated from corn silage and stored at $880^{\circ} \mathrm{C}$, and incubate in deMan Rogosa and Sharp (MRS) medium at $37^{\circ} \mathrm{C}$ for $24 \mathrm{~h}$ when used. The EN, the activity of cellulase was $50000 \mathrm{U} / \mathrm{g}$ FPase, was extracted from the $T$. reesei and purchased from Ruiyang biotechnology company (Wuxi, China). The HT2, HT3, HT4, HT5, E1C1, E1B1, C1B1, LPEN, and EN were used as the nine treatments.

Alfalfa was planted in three fields $\left(100 \mathrm{~m}^{2}\right)$ of Nanjing Agricultural University (Nanjing, China) (Humid subtropical climate, $32^{\circ} 01^{\prime} \mathrm{N}$, $118^{\circ} 50^{\prime} 13.63 "$ E, 17 masl) on September 25, 2017, and the last harvest time was November 2, 2018. Forage chopper (Sh-2000, Shanghai Donxe Industrial Co., Ltd., Shanghai, China) was used to chop the fresh alfalfa into 1 to $2 \mathrm{~cm}$ long pieces. Before ensiling, DM content, $\mathrm{pH}$ value, and BC of alfalfa were $279 \mathrm{~g} / \mathrm{kg}$ fresh matter (FM), 5.15, and 594 milliequivalents (mEq)/ $\mathrm{kg} \mathrm{DM}$, respectively. The structural carbohydrate composition: neutral detergent fiber (NDF), acid detergent fiber (ADF), acid detergent lignin (ADL), cellulose, and hemicellulose were $431,308,110,198$, and $123 \mathrm{~g} / \mathrm{kg} \mathrm{DM}$, respectively. The WSC content was $84.3 \mathrm{~g} / \mathrm{kg} \mathrm{DM}$, and the fraction of individual soluble carbohydrates was as follows: disaccharides $(24.0 \mathrm{~g} / \mathrm{kg} \mathrm{DM})$, glucose $(10.7 \mathrm{~g} / \mathrm{kg} \mathrm{DM})$, xylose $(13.7 \mathrm{~g} / \mathrm{kg} \mathrm{DM})$, arabinose $(0.21 \mathrm{~g} / \mathrm{kg} \mathrm{DM})$ and fructose $(10.5 \mathrm{~g} / \mathrm{kg} \mathrm{DM})$. The epiphytic LAB [3.40 lg colony-forming units (cfu)/g FM] on alfalfa was lower than that of aerobic bacteria (6.97 $\mathrm{lg} \mathrm{cfu/g} \mathrm{FM)} \mathrm{and} \mathrm{yeasts} \mathrm{(4.98} \mathrm{lg} \mathrm{cfu/g} \mathrm{FM).} \mathrm{The} \mathrm{fermentation} \mathrm{efficiency} \mathrm{(FC)} \mathrm{of} \mathrm{fresh} \mathrm{alfalfa} \mathrm{was} 29.04$.

Alfalfa was harvested from 3 fields ( $100 \mathrm{~m}^{2}$ each). The alfalfa harvested in each field was ensiled with nine treatments (HT2, HT3, HT4, HT5, E1C1, E1B1, C1B1, LPEN, and EN), and without treatment was the control. Each treatment and the control had four replicates. According to McFarland turbidity standards (McFarland, 1907), inoculation dosage ( $3 \mathrm{~mL}$ aqueous solution) of HT2, HT3, HT4, HT5, E1C1, E1B1, and C1B1 was at $1 \times 10^{6} \mathrm{cfu} / \mathrm{g} \mathrm{FM}$ and were sprayed on alfalfa. The EN is added to take the dose ( $3 \mathrm{~mL}$ aqueous solution) at $2 \mathrm{~g} / \mathrm{kg}$ of FM. EN and LP are mixed as LPEN, and LPEN was added at a dose ( $3 \mathrm{~mL}$ aqueous solution) of $2 \mathrm{~g} / \mathrm{kg}+1 \times 10^{6} \mathrm{cfu} / \mathrm{g} \mathrm{FM}$. Three milliliters of distilled water were added to the control. Alfalfa was mixed with different treatments and then filled into the experimental silo. The experimental silo (polyvinyl chloride bottle, 1L) was filled with $720 \mathrm{~g}$ of treated alfalfa. The silo was sealed with a lid and tape to create an anaerobic condition. All silos were kept at an ambient temperature ranging from 3 to $20^{\circ} \mathrm{C}$ for 140 days of ensiling, and then, the silos were sampled for analysis.

\section{Microbial and chemical analyses}

According to the method reported by Liu et al. (2019), the LAB, aerobic bacteria, and clostridia in alfalfa materials were counted after harvesting from the field for $2 \mathrm{~h}$. The BC of alfalfa materials was measured by the method reported by Liu et al. (2018). The DM, NDF, ADF, $A D L$, and WSC in alfalfa materials were measured by the same method reported by Li et al. (2019). The pH value was determined by mixing 50 $\mathrm{g}$ of alfalfa materials with $200 \mathrm{ml}$ of distilled water and stored at $4^{\circ} \mathrm{C}$ for $18 \mathrm{~h}$. The mixture was filled, and the pH value of filtrate was measure. The FC of alfalfa material was predicted according to the method reported by Addah et al. (2011), as follows: FC $=$ DM\% $+8 \times$ WSC $\mathrm{g} / \mathrm{kg} \mathrm{DM} \div \mathrm{BC} \mathrm{mEq} / \mathrm{kg} D M$. FC indicates whether fresh forage is easy or difficult to be ensiled ( $\mathrm{FC}>45=$ easy, $\mathrm{FC}<35=$ difficult to ensile). Freezedried and ground alfalfa samples were used to determine the contents of monosaccharides (glucose, fructose, arabinose, and xylose) and disaccharides. The sugars in fresh alfalfa were extracted with water and measured by an Agilent HPLC 1260 system equipped with chromatographic column (SP0810 sugar, Shodex, Inc. Japan) and refractive index detector. HPLC grade water was used as the mobile phase at $80^{\circ} \mathrm{C}$ and the flow rate was $0.75 \mathrm{ml} / \mathrm{min}$. The AOAC-984.13 (2000) method was used to analyze the crude protein of alfalfa materials. 
After 140 days of ensiling, the sample $(200 \mathrm{~g})$ in the center of the silo was picked up. The DM, crude protein, NDF, ADF, ADL, WSC, sugars, and microbes in the ensiled alfalfa were measured with the same methods as those in the fresh alfalfa materials. According to the formula reported by Porter et al. (1995), DM loss was calculated using the corrected DM content. The pH value, ammonia-N, alcohol, lactic acid, and volatile fatty acids in ensiled alfalfa were determined according to the method reported by Dong et al. (2019).

The oligosaccharide in WSC was analyzed by thin-layer chromatography (TLC) according to the method (Kanaya et al. 1978) and with small changes: using silica gel plate (Size: $100 \times 100$ mm; G model; Thickness of coating: 0.20-0.25mm) as chromatoplate, N-butanol: acetic acid: water (2:1:1, V/V) as a solvent system, and ethanol: sulfuric acid (4:1, V/V) as detection.

\section{Statistical analyses}

IBM SPSS Statistics software (IBM SPSS 22.0 for Windows) was used for statistical analysis. Using one-way analysis of variance (ANOVA, General Linear Models), the effects of treatments on the degradation of alfalfa lignocellulose degradation, sugar profile, fermentation characteristics, and CWL of alfalfa were evaluated. The means were then compared for significance using Tukey's test at $P<0.05$. Trends were discussed at $0.05 \leq P \leq 0.10$.

\section{Results And Discussion}

\section{Effects of combined cellulase gene engineered MG1363 on lignocellulose degradation}

After ensiling for $140 \mathrm{~d}$, treatments influenced most lignocellulosic compositions of alfalfa $(P<0.05)$, except for ADL $(P>0.05)($ Table 1$)$. It was because the ADL in lignocellulose was the hardest to be degraded during ensiling (Guo et al. 2014). Similar results were reported by Liu et al. (2019) and Li et al. (2018b), EN and LPEN treatments had lower NDF $(P<0.001$ and $P=0.011), \operatorname{ADF}(P<0.001$ and $P=0.028)$, cellulose $(P$ $<0.001$ and $P=0.003)$, hemicellulose $(P<0.001$ and $P=0.020)$, and lignocellulose $(P<0.001$ and $P=0.003)$ than the control. This was attributed to the efficient ability of cellulase to degrade the lignocellulose and its component. The LPEN had higher NDF $(P=0.026)$, ADF $(P=$ $0.020)$, cellulose $(P=0.019)$, hemicellulose $(P=0.152)$, and lignocellulose $(P=0.007)$ than the EN, which indicated that the synergistic effect of LPEN on lignocellulose degradation did not appear. This result was consistent with the findings reported by Kozelov et al. (2007), but did not agree with the results reported by Li et al. (2018). One reason for the difference in various studies was the DM content and pH value in ensiled alfalfa. Generally, ensiled forage with high-DM content caused higher pH than that with low-DM content (Mcdonald et al. 1991) and some cellulase, such as commercial T. reesi cellulase, had a great activity to degrade lignocellulose at high pH (Lan et al. 2013). Therefore, considering the higher $\mathrm{pH}$ in EN than in LPEN (Table 3) $(P=0.001)$, pH adjusted by LP was the key limiting factor for converting lignocellulose into sugar in LPEN. Similar to the LPEN, HT2 had weak lignocellulose degradation than the EN, evidenced by higher NDF $(P=0.016)$, ADF $(P=$ 0.006), cellulose $(P<0.001)$, and hemicellulose $(P=0.225)$ and lignocellulose $(P=0.004)$. This might be because the amount and activity of secreted cellulase by HT2 was insufficient and weak like in LPEN. Colombatto et al. (2004) reported that lignocellulose degradation depended on the cellulase level and acidity during ensiling.

Compared with the control, HT3, HT4, and HT5 had lower NDF $(P=0.022, P=0.011$, and $P<0.001)$, ADF $(P=0.002, P=0.002$, and $P=0.001)$, cellulose $(P=0.010, P<0.001$, and $P=0.004)$, and lignocellulose $(P=0.010, P=0.002$ and $P<0.001)$. These outcomes indicated that these combinations could promote lignocellulose degradation. Interestingly, the degradation degrees of lignocellulose in HT2 differed from that in HT3, HT4, and HT5 due to that the increase of one cellulase component gene engineered MG1363 relative to HT2 altered degradation of the lignocellulosic component. Compared with $\mathrm{HT} 2$, HT3 and $\mathrm{HT} 4$ had higher $(P=0.008$ and $P=0.083)$ residual hemicellulose content and had lower cellulose content $(P=0.182$ and $P=0.014)$. This outcome indicated that the increases of engineered MG1363 containing eg/3 or $c b h 2$ gene enhanced the cellulose degradation to promote the release of hemicellulose from the intertwined hemicellulose and ADL. The result in HT3 was agreed with the findings reported by Chylenski et al. (2017) due to the optimized hydrolysis in acidic pretreated lignocellulose biomass needed a higher proportion of EG relative to $\mathrm{CBH}$ in the cellulase cocktail. As for the outcome in HT4, this was in accordance with what is observed in nature. $\mathrm{CBH}$ had the greatest proportion (52-80\%) of the total hydrolytic enzymes secreted from Trichoderma reesei (Rosgaard et al. 2007). Furthermore, the increase of engineered MG1363 containing the cbh2 gene in the cocktail had a stronger role in decomposing the cellulose than that containing the eg/3 gene, supported by a greater cellulose-decrease level $(P=0.047)$ in HT3 than HT4 relative to the control. Kim et al. (2015) reported that, for acidic hydrolysis rice straw, the role of $\mathrm{CBH}$ was found to be more important than that of EG. In contrast, HT5 had lower contents of hemicellulose $(P=0.090)$, and lignocellulose $(P=0.017)$ than HT2. This was because increased BG promoted the degradation of hemicellulose. Indeed, some BG can degrade hemicellulose composing of xylans (Chaudhary et al.1982; Zhou et al. 2012).

Compared with the HT2, C1B1 had lower $(P=0.001)$ cellulose content. This indicated that the lack of EG did not influence the cellulose degradation and that disagreed with the traditional view of EG, $\mathrm{CBH}$, and $\mathrm{BG}$ synergistically and indispensably in degrading cellulose. The reason was the native bacteria on alfalfa secreting EG to help the engineered MG1363 containing cbh2 and bg/1 gene degrade cellulose. Zhang et al. (2019) found that two EGs produced by bacteria derived from ensiled grass, such as Paenibacillus panacisoli SDMCC050309, 
could degrade carboxymethyl cellulose into cellooligosaccharides, in which cellobiose and cellotriose could be used as substrates for the growth of homofermentative LAB. As for the ineffective EG role of native bacteria in HT2 treatment, it was because LAB in HT2 had stronger competitiveness than that in $\mathrm{C} 1 \mathrm{~B} 1$, supported by more $\mathrm{LAB}(P<0.001)$ and less aerobic bacteria $(P=0.017)$, and Clostridia spore $(P<0.001)$ in HT2 than C1B1 (Table 3). Compared with HT2, the lack of the engineered MG1363 containing cbh2 gene markedly influenced the lignocellulose degradation, mainly in hemicellulose, demonstrated by higher contents of hemicellulose $(P<0.001)$ and lignocellulose $(P=$ $0.001)$ in E1B1 treatment. This indicated that the lack of CBH went against the degradation of hemicellulose. It was because that CBH was the main component of cellulase and can degrade hemicellulose (Wei et al. 2017). The lack of engineered MG1363 containing bg/1 gene in E1C1 did not influence the lignocellulosic degradation relative to $\mathrm{HT} 2$ treatment囚indicated by insignificant differences in NDF, ADF, cellulose, and hemicellulose between E1C1 and HT2 $(P>0.05)$. The reason might be that the MG1363 host could utilize the productions decomposed by EG and $\mathrm{CBH}$. Therefore, $\mathrm{CBH}$ played a more key role in lignocellulose degradation than $\mathrm{EG}$ and $\mathrm{BG}$ during ensiling.

\section{Effects of combined cellulase gene engineered MG1363 on oligosaccharide}

As shown in TLC, big molecular-weight oligosaccharides were in the FAM, HT4, HT5, and E1B1 and C1B1 due to the shadow area in the lanes and there were markable small molecular-weight oligosaccharides in all samples (Fig. 1). The former indicated that the broken degree of lignocellulose was greater in HT4, HT5, E1B1, and C1B1 compared with other treatments, while the latter suggested that these small molecularweight oligosaccharides were not utilized by MG1363 host and native LAB on alfalfa during ensiling. Fewer small molecular-

weight oligosaccharides were in the LPEN compared with the EN, HT3, HT4, HT5, and the control due to its light blots. This could be explained by Lactob. plantarum had a wider fermentation profile of sugar than MG1363 host and native LAB on alfalfa. Liu et al. (2020) reported that Lactob. plantarum could ferment xylose while MG1363 and E. faecalis could not. Interestingly, one blot of small molecular-weight oligosaccharides in E1C1, and C1B1 relative to the two blots of small molecular-weight oligosaccharides in the EN, HT2, HT3, HT4, HT5, E1B1, and the control indicated that low sugar diversity in E1C1 and C1B1 due to the consumption of native bacteria or not being cut from lignocellulose. Especially, two blots of small molecular-weight oligosaccharides in the HT4 and HT5 were darker than those in the EN, LPEN, HT2, HT3, and the control. This indicated that more small-molecular oligosaccharides were released from lignocellulose but could not be fermented in treatments of HT4 and HT5.

\section{Effects of combined cellulase gene engineered MG1363 on sugar profile}

As shown in Table 2, the control had lower WSC than EN $(P=0.001)$, LPEN $(P=0.001), \mathrm{HT} 2(P=0.067)$, and HT3 $(P<0.001)$ after ensiling for $140 \mathrm{~d}$, which inferred that more WSC were released from lignocellulose due to lower lignocellulose in $\operatorname{EN}(P<0.001), \operatorname{LPEN}(P=0.005)$, and HT2 $(P=0.010)$ (Table 1). In contrast, there was lower WSC content in HT5 $(P<0.001)$ compared with the control, and HT4, C1B1, E1B1, and E1C1 had approximate WSC with the control $(P>0.05)$. The former resulted from that the sugars derived from the lignocellulose degradation could be fermented by MG1363 host on alfalfa during ensiling. This was supported by fewer NDF $(P<0.001), \operatorname{ADF}(P=0.001)$, cellulose $(P=$ $0.004)$ and hemicellulose $(P<0.001)$ and more LA $(P<0.001)$ in HT5 than the control (Table 3$)$. Interestingly, the reasons for the low WSC in HT4, C1B1, E1B1, E1C1, and the control were different. Similar to HT5, low WSC content in HT4 was because that WSC released from lignocellulose degradation could be fermented by MG1363 host during ensiling due to the extra engineered MG1363 containing $c b h 2$ gene. Furthermore, the WSC consumption-ability of HT5 was stronger than HT4. The detailed reason was unknown since there was no difference in the bacteria compositions, and thus which needed further study in the future. Conversely, the low WSC in the control and E1B1 indicated that few fermentable WSC derived from the lignocellulose degradation due to the high lignocellulose composition (Table 1). Consequently, the inherent WSC in alfalfa was consumed in the control and E1B1. The low WSC in the C1B1 and E1C1 was because that the WSC derived from the lignocellulose degradation could be fermented, supported by the lower lignocellulose $(P<0.001)$ and higher LA content $(P=0.002$ and $P<$ 0.001) than the control (Table 3).

Compared with the control, most of treatments had higher disaccharide $(P<0.05)$, except for HT4 $(P>0.05)$. The explanation for the former was that disaccharide was formed from lignocellulose degradation and was not consumed by Lactoc. latics and some native bacteria on the alfalfa. The latter indicated that the HT4 not only strongly converted lignocellulose into disaccharide but also had the strongest ability to consume the disaccharide. The extra CBH secreted by engineered MG1363 strain containing cbh2 gene in HT4 could attack the non-reducing end of the crystalline cellulose created by EG and release cellobiose (Chylenski et al. 2017), which could be further cut by BG into monosaccharide and was fermented by Lactoc. latics host to produce more LA than other treatments $(P<0.001)$ (Table 3). Amazingly, the lack of engineered MG1363 strain containing the $c b h 2$ gene in E1B1 resulted in higher disaccharide content than HT4 $(P<0.001)$. It was hard to explain the disaccharide source. The proposed reason might be that the end of the crystalline cellulose created by EG could be digested into disaccharides in an acidic ensiling environment. The higher disaccharide content in EN, HT2, HT3, HT5, and LPEN than in HT4 might be because the consumption level of disaccharide in the above treatments was weaker than in HT4. On the other hand, HT3 had the highest disaccharide content than other treatments. This might result from the extra EG secreted by engineered MG1363 strain containing eg/3 gene in HT3 could produce quite a number of the ends of the cellulose crystallinity to restrain the CBH and BG activity. Some studies reported that cellulase adsorption generally declined as cellulose crystallinity increased (Yang et al. 2011). Crystallinity could greatly impact the adsorption 
of Cel7A (CBHI), leading to the decrease of hydrolysis (Jeoh et al. 2007). Cello-oligosaccharide substrates inhibited the activity of BG (Kawai et al. 2004; Bohlin et al. 2013; Teugjas and VaLjamaE, 2013). Consequently, the channel of cellobiose converting into glucose was blocked by disaccharides which accumulated in HT3. Interestingly, LPEN had higher disaccharide contents than EN $(P<0.05)$. This indicated that the ability of the native LAB on the alfalfa material to ferment disaccharides was weaker than that of Lactob. plantarum.

All treatments had higher xylose than the control $(P<0.05)$, except for LPEN (Fig. 2). The reasons for the former were as follows: $\nabla$ xylose was hardly metabolized by the MG1363 (Erlandson et al. 2000) $\otimes$ Some native LAB in the control could utilize xylose. Cai found that some isolated native LAB from forage crops, such as Enteric. casseliflavus and Enteric. gallinarum, and Enteric. mundtii, could ferment xylose (Cai, 1999). $\otimes$ EN degraded more hemicellulose $(P<0.001)$ into xylose than the control. The reason for the latter was that $L a c t o b$. plantarum could ferment xylose. Our previous study reported that the MG1363 had the weaker ability to ferment xylose than Lactob. plantarum (Liu et al. 2019). Compared with the control, higher arabinose content in HT4 $(P<0.001)$, EN $(P<0.001)$, and LPEN $(P<0.001)$ indicated that hemicellulose was degraded into arabinose due to lower hemicellulose content $(P=0.384, P<0.001$, and $P<0.001)$ than the control and the extra engineered MG1363 strain containing cbh2 gene in HT4 relative to HT2, HT3, HT5, C1B1, E1B1, and E1C1 could cut hemicellulose to release arabinose.

\section{Effects of combined cellulase gene engineered MG1363 on the fermentative characteristics and microbial compositions of ensiled alfalfa}

As shown in Table 3, compare with the control, all treatments improved the fermentation due to their lower $\mathrm{pH}$ values $(P<0.05)$, ammonia- $\mathrm{N}$ contents $(P<0.05)$ and DM losses $(P<0.05)$, and higher LA contents $(P<0.05)$. It was because that cellulase derived from the EN and secreted by engineered Lactoc. latics combination could degrade lignocellulose into the sugars to enhance the LA fermentation of $L a c t o c$. latics and native LAB. Interestingly, EN promoted the LA fermentation but did not decrease the acetic acid (AA) content $(P=0.750)$ compared with the control. One reason was that cellulase has an affinity with hemicellulose. The AA and sugars are hemicellulose hydrolyzed production of cellulase (Zheng et al. 2017). Another reason was that EN promoted the hetero-LA fermentation of native LAB on alfalfa, supported by high DM loss and ammonia-N than other treatments. Hetero-LA fermentation was associated with high DM loss, concentrations of AA, and ammonia-N during ensiling compared with homo-LA fermentation (Driehuis et al. 1999).

Compared with EN, DM loss $(P<0.05)$ and AA content $(P<0.05)$ were decreased by the supplementations of HT2, HT3, HT4, HT5, LPEN, E1C1, E1B1, and C1B1, accompanied with higher LA/AA $(P<0.05)$ and lower ammonia-N $(P<0.05)$. This result indicated that the homo-LA fermentation was more vigorous in those treatments than in EN. Liu et al. (2019) demonstrated that engineered homo-fermentative LAB strains containing cellulase gene or the combination of wild-type MG1363 and cellulase had stronger homo-LA fermentation in ensiled alfalfa compared with adding cellulase alone. Tian et al. (2014) and Xing et al. (2009) found that Lactob. plantarum combined with cellulase promoted homo-LA fermentation and inhibited the degradation of protein to produce ammonia-N.

Interestingly, compared with the HT2, increasing engineered MG1363 containing one gene of cellulase component altered the LA fermentation. The greatest LA content in the HT4 $(P<0.05)$ and was higher than the HT2 $(P=0.013)$ indicated that increasing engineered MG1363 with the $c b h 2$ gene had a better effect on promoting LA fermentation. In addition, relative to HT2, increasing engineered MG1363 containing $c b h 2$ gene was better than increasing engineered MG1363 with eg/3 or bg/1 gene on increasing LA content $(P<0.001)$, supported by HT4 having higher LA content $(P<0.05)$ and CWL $(P=0.004$ and $P<0.001)$ than HT3 and HT5 (Fig. 3). This demonstrated that the CBH was the key cellulase component for degrading lignocellulose into fermentable sugar, and followed by MG1363 host converted sugar into more LA, supported by lower cellulose $(P=0.014)$, fewer fermentable disaccharides $(P<0.001)$, and higher LA content $(P=0.013)$ in HT4 than HT2. Therefore, CBH cellobiohydrolase better cooperated with MG1363 to ferment lignocellulose into LA than endoglucanase and $\beta$-glucosidase.

Although there were lower LA content $(P<0.001)$ and CWL $(P=0.038$ and $P<0.001)$ in HT3 and HT5 relative to HT2, the mechanisms of altering LA fermentation were different in HT3 and HT5. Compared with HT2, the channel of fermenting sugar into LA in HT3 was restrained rather than that of converting lignocellulose into sugar since HT3 had approximate residual WSC $(P=0.385)$ and lignocellulose content $(P=$ $0.788)$ and lower LA content $(P<0.001)$ and CWL $(P=0.038)$ relative to HT2. In contrast, the channel of converting lignocellulose into sugar in HT5 was not restrain since HT5 had lower lignocellulose $(P=0.017)$ relative to HT2. Whereas, the channel of fermenting sugar into LA in HT5 was restrained, supported by its lower contents of residual WSC $(P<0.001)$ and LA $(P<0.001)$ and the CWL $(P<0.001)$ relative to HT2 $(P=$ 0.001). On the other hand, LPEN had lower LA content $(P=0.001)$, approximate CWL $(P=0.374)$, residual WSC $(P=0.072)$, and lignocellulose $(P=0.795)$ relative to $\mathrm{HT} 2$ and had weaker $(P=0.004)$ lignocellulose degradation relative to $\mathrm{EN}$ due to the lower $\mathrm{pH}$, which indicated that the $\mathrm{pH}$ was the key limiting factor for lignocellulose saccharification of commercial EN in the simultaneous saccharification and fermentation of LPEN. This might be one explanation to clarify the weak or no effect on reducing the contents of NDF and ADF and improving the LA fermentation in ensiled alfalfa treated with the combination of cellulase and LAB in previous studies (Kozelov et al. 2007; Lynch et al. 2014). Therefore, selecting cellulase combined with LAB strain for fermenting lignocellulosic grass to produce LA needs careful consideration.

Accordingly, the lack of any engineered MG1363 containing one gene of cellulase component in C1B1, E1B1, or E1C1 had lower LA production $(P<0.001)$ compared with HT2. This outcome could be explained by followed reasons: $\nabla$ fewer LAB numbers in C1B1 $(P<0.001)$, E1B1 $(P=$ 
0.043), and E1C1 $(P<0.001)$ than the HT2; $\nabla$ the insufficient unblocked channel of converting lignocellulose into sugar was in E1B1 due to its higher residual lignocellulose $(P=0.001)$ than the $\mathrm{HT} 2$; $\otimes$ the insufficient unblocked channels of converting sugar into LA were in $\mathrm{C} 1 \mathrm{~B} 1$ and E1C1 due to their lower LA content $(P<0.001)$ and CWL $(P<0.001)$ than HT2. Therefore, we optimized the cocktail of engineered MG1363 containing cellulase component gene to promote LA fermentation and clarify the key cellulase component playing synergistic role with $L A B$ in fermenting alfalfa lignocellulose into LA, and identified the synergetic disadvantage of cellulase combined with LAB for LA fermentation in ensiled alfalfa feedstock.

\section{Conclusions}

HT4 was the optimal combination proportions (at 1:2:1) of engineered MG1363 containing bg/1, cbh2 and eg/3 genes and could improve LA fermentation maximally. The cocktail of cellulase gene engineered MG1363 clarified the CBH played more key in converting lignocellulose into fermentable sugar than EG and BG and cooperated with MG1363 host to produce more LA content. The pH was the key limiting factor for lignocellulose saccharification of commercial EN in the simultaneous saccharification and fermentation of the combination of Lactob. plantarum and cellulase in ensiled alfalfa. This study could benefit the development of LA production in fermenting lignocellulosic biomass via optimizing the cocktail of cellulase gene engineered LAB.

\section{Abbreviations}

ADF, Acid detergent fiber; ADL, Acid detergent lignin; BC, Buffering capacity; $\mathrm{CBH}$, Cellobiohydrolase; EN, Cellulase; Control, alfalfa ensiled without treatments; CWL, Conversion of WSC into la; cfu, colony-forming units; MRS, Deman rogosa and sharp; DM, Dry matter; EG, Endoglucanase; FAM, fresh alfalfa material; FC, Fermentation efficiency; FM, Fresh matter; HT2, HT3, HT4, HT5, E1C1, E1B1, and C1B1, combined engineered Lactococcus lactis subsp. lactis MG1363 strains containing eg/3, cbh2, and bg/1 gene mixed at proportions of 1:1:1, 2:1:1, 1:2:1, 1:1:2, 1:1:0, 1:0:1, and 0:1:1, separately; LA, Lactic acid; LA/AA, the ratio of lactic acid to acetic acid; LAB, Lactic acid bacteria; LPEN, Lactobacillus plantarum and cellulase; NDF, Neutral detergent fiber; $\mathrm{NH}_{3}-\mathrm{N}$, ammonia-N; $\mathrm{N}$, nitrogen; SEM, standard error of the means; TLC, Thin-layer chromatography; WSC, Water-soluble carbohydrates; BG, $\beta$-Glucosidase.

\section{Declarations}

\section{Authors' contributions}

Professor Qinhua Liu and Tao Shao designed the experiment. Dr. Junfeng Li, Master student Qifeng Wu, Cheng Zong, Aili Wu, Dr. Zhihao Dong experimented using the methods in the related references. Dr. Junfeng Li and Professor Qinhua Liu edited the manuscript and Tao Shao provided language service. Professor Qinhua Liu, as the corresponding author, submitted this paper.

\section{Funding}

This work was supported by China Postdoctoral Science Foundation [grant number: 2019M651865], National Natural Science Foundation of China (grant number: 31901391), and National Natural Science Foundation of China (grant number: 31971765).

\section{Availability of data and materials}

Not applicable.

\section{Ethics approval and consent to participate}

Not applicable.

\section{Consent for publication}

Not applicable.

\section{Competing interests}

The authors declare that they have no competing interests.

\section{References}

Addah W, Baah J, Groenewegen P, Okine EK, McAllister TA (2011) Comparison of the fermentation characteristics, aerobic stability and nutritive value of barley and corn silages ensiled with or without a mixed bacterial inoculant. Can J Anim Sci 91(1): 133-146. 
Alexandri M, Schneider R, Mehlmann K, Venus J (2019) Recent Advances in D-Lactic Acid Production from Renewable Resources: Case Studies on Agro-Industrial Waste Streams. Food Technol Biotech 57(3):293-304. doi:10.17113/ftb.57.03.19.6023

AOAC-984.13 (1990) Protein (crude) in animal feed. Copper catalyst Kjeldahl method, In Official Methods of Analysis of the Association of Official Analytical Chemists, 15th ed Association of Official Analytical Chemistry

Bichot A, Delgenes JP, Mechin V, Carrere H, Bernet N, Garcia-Bernet D (2018) Understanding biomass recalcitrance in grasses for their efficient utilization as biorefinery feedstock. Rev Environ Sci Biotechnol 17(4):707-748. doi:10.1007/s11157-018-9485-y

Bohlin C, Praestgaard E, Baumann MJ, Borch K, Praestgaard J, Monrad RN, Westh PJAMB (2013) A comparative study of hydrolysis and transglycosylation activities of fungal $\beta$-glucosidases. Appl Microbiol Biotechnol 97(1): 159-169. doi:10.1007/s00253-012-3875-9

Cai YM (1999) Identification and characterization of Enterococcus species isolated from forage crops and their influence on silage fermentation. J Dairy Sci 82(11):2466-2471. doi:10.3168/jds.S0022-0302(99)75498-6

Cao Y, Cai YM, Hirakubo T, Fukui H, Matsuyama H (2011) Fermentation characteristics and microorganism composition of total mixed ration silage with local food by-products in different seasons. Anim Sci J 82(2):259-266. doi:10.1111/j.1740-0929.2010.00840.x

Chaudhary K, Tauro P (1982) Selective induction of $\beta$-glucosidase in Trichoderma reesei by xylan. European

J Appl Microbiol Biotechnol 15(3):185-187. doi:10.1007/BF00511246

Chylenski P, Forsberg Z, Stahlberg J, Varnai A, Lersch M, Bengtsson O, Eijsink VGH (2017) Development of minimal enzyme cocktails for hydrolysis of sulfite-pulped lignocellulosic biomass. J Biotechnol 246:16-23. doi:10.1016/j.jbiotec.2017.02.009

Colombatto D, Mould FL, Bhat MK, Phipps RH, Owen E (2004) In vitro evaluation of fibrolytic enzymes as additives for maize (Zea mays L.) silage. Anim Feed Sci Tech 111(1-4):111-128. doi:10.1016/j.anifeedsci.2003.08.011

DeCker C, Visser J, Schreier PJAM (2001) ß-Glucosidase multiplicity from Aspergillus tubingensis CBS 643.92: Purification and characterization of four $\beta$-glucosidases and their differentiation with respect to substrate specificity, glucose inhibition and acid tolerance. Appl Microbioll Biot 55(2):157-163. doi:10.1007/s002530000462

Dong ZH, Chen L, Li JF, Yuan XJ, Shao T (2019) Characterization of nitrogen transformation dynamics in alfalfa and red clover and their mixture silages. Grassl Sci 65(2):109-115. doi:10.1111/grs.12230

Driehuis F, Elferink S, Spoelstra SF (1999) Anaerobic lactic acid degradation during ensilage of whole crop maize inoculated with Lactobacillus buchneri inhibits yeast growth and improves aerobic stability. J Appl Microbiol 87(4):583-594. doi:10.1046/j.1365-2672.1999.00856.x

Du J, Liang JR, Gao XH, Liu GD, Qu YB (2020) Optimization of an artificial cellulase cocktail for high-solids enzymatic hydrolysis of cellulosic materials with different pretreatment methods. Bioresour Technol 295:122272. doi:10.1016/j.biortech.2019.122272

Du J, Song WX, Zhang X, Zhao J, Liu GD, Qu YB (2018) Differential reinforcement of enzymatic hydrolysis by adding chemicals and accessory proteins to high solid loading substrates with different pretreatments. Bioproc Biosyst Eng 41(8):1153-1163. doi:10.1007/s00449-018-1944-x

Erlandson KA, Park JH, El Khal W, Kao HH, Basaran P, Brydges S, Batt CA (2000) Dissolution of xylose metabolism in Lactococcus lactis. Appl Environ Microb 66(9):3974-3980. doi:10.1128/AEM.66.9.3974-3980.2000

Galkin MV, Samec JSM (2016) Lignin Valorization through Catalytic Lignocellulose Fractionation: A Fundamental Platform for the Future Biorefinery. Chemsuschem 9(13):1544-1558. doi:10.1002/cssc.201600237

Guo G, Yuan XJ, Li LX, Wen AY, Shao T (2014) Effects of fibrolytic enzymes, molasses and lactic acid bacteria on fermentation quality of mixed silage of corn and hulless-barely straw in the Tibetan Plateau. Grassl Sci 60(4):240-246. doi:10.1111/grs.12060

Haag NL, Grumaz C, Wiese F, Kirstahler P, Merkle W, Nagele HJ, Oechsner H (2016) Advanced green biorefining: effects of ensiling treatments on lactic acid production, microbial activity and supplementary methane formation of grass and rye. Biomass Convers Bior 6(2):197-

208. doi:10.1007/s13399-015-0178-2

Jeoh T, Ishizawa Cl, Davis MF, Himmel ME, Adney WS, Johnson DK (2007) Cellulase digestibility of pretreated biomass is limited by cellulose accessibility. Biotechnol Bioeng 98(1):112-122. doi: 10.1002/bit.21408

Page 8/14 
Kanaya K, Chiba S, Shimomura T (1978) Thin-layer Chromatography of Linear Oligosaccharides. Agric Biol Chem 42(10):19471948. doi:10.1080/s13399-015-0178-2

Kawai R, Igarashi K, Kitaoka M, Ishii T, Samejima MJCR (2004) Kinetics of substrate transglycosylation by glycoside hydrolase family 3 glucan $(1 \rightarrow 3)$-beta-glucosidase from the white-rot fungus Phanerochaete chrysosporium. Carbohyd Res 339(18):2851-

2857. doi:10.1016/j.carres.2004.09.019

Kim IJ, Jung JY, Lee HJ, Park HS, Jung YH, Park K, Kim KH (2015) Customized optimization of cellulase mixtures for differently pretreated rice straw. Bioproc Biosyst Eng 38(5):929-937. doi: 10.1007/s00449-014-1338-7

Kozelo, LK, lliev F, Hristov AN, Zaman S, McAllister TA (2007) Effect of fibrolytic enzymes and an inoculant on in vitro digestibility and gas production of low-dry matter alfalfa silage. J Anim Sci 85:285-285. doi: 10.1002/jsfa.3393

Kung L (2015) Silage Additives: where are we going XVII International Silage Conference.

Lan TQ, Lou HM, Zhu JY (2013) Enzymatic Saccharification of Lignocelluloses Should be Conducted at Elevated pH 5.2-6.2. Bioenerg Res 6(2):476-485. doi:10.1007/s12155-012-9273-4

Li DX, Ni KK, Zhang YC, Lin YL, Yang FY (2018) Influence of lactic acid bacteria, cellulase, cellulase-producing Bacillus pumilus and their combinations on alfalfa silage quality. J Integr Agr 17(12):2768-2782. doi:10.1016/S2095-3119(18)62060-X

Li JF, Yuan XJ, Desta ST, Dong ZH, Mugabe W, Shao T (2018a) Characterization of Enterococcus faecalis JF85 and Enterococcus faecium Y83 isolated from Tibetan yak (Bos grunniens) for ensiling Pennisetum sinese. Bioresour Technol 257:76-83. doi:10.1016/j.biortech.2018.02.070

Li JF, Yuan XJ, Dong ZH, Mugabe W, Shao T (2018b) The effects of fibrolytic enzymes, cellulolytic fungi and bacteria on the fermentation characteristics, structural carbohydrates degradation, and enzymatic conversion yields of Pennisetum sinese silage. Bioresour Technol 264:123-130. doi:10.1016/j.biortech.2018.05.059

Liu QH, Dong ZH, Shao T (2018) Effect of additives on fatty acid profile of high moisture alfalfa silage during ensiling and after exposure to air. Anim Feed Sci Tech 236:29-38. doi: 10.1016/j.anifeedsci.2017.11.022

Liu QH, Li JF, Zhao J, Wu JX, Shao T (2019) Enhancement of lignocellulosic degradation in high-moisture alfalfa via anaerobic bioprocess of engineered Lactococcus lactis with the function of secreting cellulase. Biotechnol Biofuels 12. doi:10.1186/s13068-019-1429-4

Liu QH, Zong C, Dong ZH, Wu JX, Zhu JG, Li JF, Shao T (2020) Effects of cellulolytic lactic acid bacteria on the lignocellulose degradation, sugar profile and lactic acid fermentation of high-moisture alfalfa ensiled in low-temperature seasons. Cellulose 27(14):79557965. doi:10.1007/s10570-020-03350-z

Lynch JP, Jin L, Lara EC, Baah J, Beauchemin KA (2014) The effect of exogenous fibrolytic enzymes and a ferulic acid esterase-producing inoculant on the fibre degradability, chemical composition and conservation characteristics of alfalfa silage. Anim Feed Sci Tech 193:2131. doi: 10.1016/j.anifeedsci.2014.03.013

Martinez FAC, Balciunas EM, Salgado JM, Gonzalez JMD, Converti A, Oliveira RPD (2013) Lactic acid properties, applications and production: A review. Trends Food Sci Tech 30(1):70-83. doi:10.1016/j.tifs.2012.11.007

McDonald P (1981) The biochemistry of silage. Chichester; New York: J. Wiley.

Mcdonald P, Henderson AR, Heron SJJW (1991) The biochemistry of silage. Chichester, New York: J. Wiley.

McFarland J (1907) The nephelometer:an instrument for estimating the number of bacteria in suspensions used for calculating the opsonic index and for vaccines. J Am Med Assoc xlix(14), 1176-1178. doi:10.1001/jama.1907.25320140022001f

Method 984.13, Protein (Crude) in Animal Feed and Pet Food. Official Methods of Analysis. (2000).

Porter MG, Steen RWJ, Kilpatrick DJ, Gordon FJ, Mayne CS, Poots RE, Pippard CJ (1995) Electrometric titration as a method of predicting the chemical composition and corrected dry matter concentration of silage. Anim Feed Sci Tech 56(3-4): 217-230. doi: 10.1016/0377-

8401(95)00831-4

Riou C, Salmon JM, Vallier MJ, Gunata Z, Barre P (1998) Purification, characterization, and substrate specificity of a novel highly glucosetolerant beta-glucosidase from Aspergillus oryzae. Appl Environ Microb 64(10):3607-3614. doi:10.1089/oli.1.1998.8.435

Page 9/14 
Rosgaard L, Pedersen S, Langston J, Akerhielm D, Cherry JR, Meyer AS (2007) Evaluation of minimal Trichoderma reesei cellulase mixtures on differently pretreated barley straw substrates. Biotechnol Progr 23(6):1270-1276. doi:10.1021/bp070329p

Stokes MR, Chen J (1994) Effects of an enzyme-inoculant mixture on the course of fermentation of corn silage. J Dairy Sci 77(11):34013409. doi:10.3168/jds.S0022-0302(94)77282-9

Tarraran L, Mazzoli R (2018) Alternative strategies for lignocellulose fermentation through lactic acid bacteria: the state of the art and perspectives. Fems Microbiol Lett 365(15). doi:10.1093/femsle/fny126

Teugjas H, Väljamäe PJB (2013) Selecting $\beta$-glucosidases to support cellulases in cellulose saccharification. Biotechnol Biofuels 6(1):105. doi:10.1186/1754-6834-6-105

Tian JP, Yu YD, Yu Z, Shao T, Na RS, Zhao MM (2014) Effects of lactic acid bacteria inoculants and cellulase on fermentation quality and in vitro digestibility of Leymus chinensis silage. Grassl Sci 60(4): 199-205. doi:10.1111/grs. 12059

Wang SR, Yuan XJ, Dong ZH, Li JF, Shao T (2017) Isolating and evaluating lactic acid bacteria strains for effectiveness on silage quality at low temperatures on the Tibetan Plateau. Anim Sci J 88(11):1722-1729. doi:10.1111/asj.12852

Wee YJ, Kim JN, Ryu HW (2006) Biotechnological production of lactic acid and its recent applications. Food Technol Biotech 44(2):163-

172. doi:10.1016/j.fm.2005.03.004

Wei H, Yan Y, Gu J, Yi W, Tang J (2017) Lignocellulosic Biomass Valorization: Production of Ethanol: Reference Module in Earth Systems and Environmental Sciences.

Xing L, Chen L J, Han LJ (2009) The effect of an inoculant and enzymes on fermentation and nutritive value of sorghum straw silages. Bioresour Technol 100(1):488-491. doi: 10.1016/j.biortech.2008.06.017

Yang B, Dai Z, Ding SY, Wyman CE (2011) Enzymatic hydrolysis of cellulosic biomass. Future Science Group 2(4):421-450. doi: 10.4155/BFS.11.116

Zhang SS, Xu ZS, Wang T, Kong J (2019) Endoglucanase improve the growth of homofermentative Lactobacillus spp. in ensilages. J Biotechnol 295:55-62. doi: 10.1016/j.jbiotec.2019.02.010

Zhou J, Bao L, Chang L, Liu Z, You C, Lu H (2012) Beta-xylosidase activity of a GH3 glucosidase/xylosidase from yak rumen metagenome promotes the enzymatic degradation of hemicellulosic xylans. Lett Appl Microbiol 54(2):79-87. doi.org/10.1111/j.1472-765x.2011.03175.x

\section{Tables}

Table 1 Chemical compositions of alfalfa before and after ensiling for $140 \mathrm{~d}^{\mathrm{a}}$ 


\begin{tabular}{|c|c|c|c|c|c|c|c|c|}
\hline \multirow[t]{2}{*}{ Items $^{b}$} & \multirow{2}{*}{$\begin{array}{l}\text { DM } \\
(g / k g F W)\end{array}$} & $\mathrm{CP}$ & NDF & ADF & ADL & Cellulose & Hemicellulose & Lignocellulose \\
\hline & & \multicolumn{7}{|c|}{ (g/kg DM) } \\
\hline FAM & 279 & 229 & 431 & 308 & 110 & 198 & 123 & 431 \\
\hline CON & $236^{e}$ & 237 & $390^{a}$ & $277^{a}$ & 100 & $178^{a}$ & $112^{a b}$ & $390^{a}$ \\
\hline EN & 247 de & 227 & $335^{c}$ & $242^{d}$ & 97.9 & $144^{d}$ & $93.2^{d}$ & $335^{d}$ \\
\hline LPEN & $254^{b c d}$ & 246 & $361^{b}$ & $260^{b c}$ & 102 & 158 bc & $101^{c d}$ & $361^{b}$ \\
\hline HT2 & $251^{\mathrm{cd}}$ & 233 & $363^{b}$ & $264^{a b c}$ & 94.8 & $169^{a b}$ & $99.4^{\mathrm{cd}}$ & $363^{b}$ \\
\hline HT3 & $271^{a}$ & 237 & $364^{b}$ & $251^{\mathrm{cd}}$ & 90.8 & $161^{b c}$ & $114^{a b}$ & $365^{b}$ \\
\hline HT4 & $249^{c d}$ & 245 & $360^{b}$ & $252^{c d}$ & 98.5 & $154^{\mathrm{cd}}$ & $108^{b c}$ & $360^{b}$ \\
\hline HT5 & $250^{c d}$ & 244 & $340^{b c}$ & $250^{c d}$ & 90.8 & 159 bc & $90.6^{d}$ & $340^{c d}$ \\
\hline C1B1 & $265^{a b}$ & 242 & $357^{b c}$ & $257^{b c d}$ & 109 & $148^{c d}$ & $100^{c d}$ & $357^{b c}$ \\
\hline E1B1 & $255^{b c d}$ & 235 & $395^{a}$ & $272^{a b}$ & 97.7 & $174^{a}$ & $123^{a}$ & $394^{a}$ \\
\hline E1C1 & $261^{a b c}$ & 239 & 349 bc & $257^{b c d}$ & 85.8 & $171^{a b}$ & $92.9^{d}$ & 349 bcd \\
\hline SEM & 2.5 & 4.9 & 7.7 & 5.2 & 5.5 & 4.1 & 3.5 & 6.3 \\
\hline $\begin{array}{l}\text { 1. Value } \\
\text { 2. CON vs All treatment }\end{array}$ & $<0.001$ & 0.179 & $<0.001$ & 0.002 & 0.230 & $<0.001$ & $<0.001$ & $<0.001$ \\
\hline
\end{tabular}

a Before ensiling means that alfalfa material is sampled after harvesting from the field for $2 \mathrm{~h}$, and is not fermented in anaerobic silos; After ensiling means that alfalfa material is fermented in anaerobic silo for $140 \mathrm{~d}$ and sampled after silo opened.

${ }^{b}$ Means in a column without a common superscript letter differed $(P<0.05)$ as analyzed by one-way ANOVA and the Tukey test. CP, crude protein; DM, dry matter; NDF, neutral detergent fiber assayed with a heat-stable amylase and expressed inclusive of residual ash; ADF, acid detergent fiber expressed inclusive of residual ash; ADL, acid detergent lignin; FAM, fresh alfalfa material; Control, alfalfa ensiled without treatments; EN, cellulase; LPEN, the combination of Lactobacillus plantarum and cellulase; Lignocellulose, the sum of ADL, cellulose, and hemicellulose; HT2, HT3, HT4, HT5, E1C1, E1B1, and C1B1, combined engineered Lactococcus lactis subsp. lactis MG1363 strains containing eg/3, cbh2, and $b g / 1$ gene mixed at proportions of 1:1:1, 2:1:1, 1:2:1, 1:1:2, 1:1:0, 1:0:1, and 0:1:1, separately; SEM, standard error of the means.

Table 2 Sugars of alfalfa before and after ensiling for $140 \mathrm{~d}^{\mathrm{a}}$ 


\begin{tabular}{|c|c|c|c|c|c|c|}
\hline \multirow[t]{2}{*}{ Items ${ }^{b}$} & \multirow{2}{*}{$\begin{array}{l}\text { Water-soluble } \\
\text { carbohydrates } \\
\text { (g/kg DM) }\end{array}$} & \multirow{2}{*}{$\begin{array}{l}\text { Disaccharide } \\
\text { (g/kg DM) }\end{array}$} & \multicolumn{4}{|c|}{ Monosaccharide (g/kg DM) } \\
\hline & & & Glucose & Xylose & Arabinose & Fructose \\
\hline FAM & 84.3 & 24.0 & 10.7 & 13.7 & 0.21 & 10.5 \\
\hline CON & $35.9^{b c}$ & $0.00^{f}$ & / & $16.8^{c}$ & $0.00^{c}$ & / \\
\hline EN & $42.8^{a}$ & $7.59^{c}$ & / & $19.1^{\mathrm{a}}$ & $0.24^{a}$ & / \\
\hline LPEN & $42.8^{a}$ & $9.31^{b}$ & / & $17.7^{\mathrm{bc}}$ & $0.24^{a}$ & / \\
\hline HT2 & $39.4^{a b}$ & $8.64^{b c}$ & / & $19.2^{\mathrm{a}}$ & $0.08^{b c}$ & / \\
\hline HT3 & $43.7^{a}$ & $10.9^{a}$ & / & $19.4^{\mathrm{a}}$ & $0.02^{c}$ & 0.08 \\
\hline HT4 & $35.3^{b c}$ & 1.02 ef & / & $18.5^{a b}$ & $0.20^{a}$ & / \\
\hline HT5 & $26.2^{d}$ & $8.28^{b c}$ & / & $18.6^{a b}$ & $0.04^{b c}$ & 0.06 \\
\hline C1B1 & $34.4^{c}$ & $4.13^{d}$ & / & $18.9^{a}$ & $0.02^{c}$ & 1.04 \\
\hline E1B1 & $36.0^{b c}$ & $4.52^{d}$ & / & $18.7^{a b}$ & $0.08^{b c}$ & / \\
\hline E1C1 & $34.9^{b c}$ & $2.24^{\mathrm{e}}$ & / & $18.6^{a b}$ & $0.14^{c}$ & 0.10 \\
\hline SEM & 1.42 & 0.544 & / & 0.33 & 0.034 & / \\
\hline P-Value & $<0.001$ & $<0.001$ & / & $<0.001$ & $<0.001$ & / \\
\hline
\end{tabular}

a Before ensiling means that alfalfa material is sampled after harvesting from the field for $2 \mathrm{~h}$, and is not fermented in anaerobic silos; After ensiling means that alfalfa material is fermented in anaerobic silo for $140 \mathrm{~d}$ and sampled after silo opened.

${ }^{b}$ Means in a column without a common superscript letter differed $(P<0.05)$ as analyzed by one-way ANOVA and the Tukey test. FAM, fresh alfalfa material; Control, alfalfa ensiled without treatments; EN, cellulase; LPEN, the combination of Lactobacillus plantarum and cellulase; HT2, HT3, HT4, HT5, E1C1, E1B1, and C1B1, combined engineered Lactococcus lactis subsp. lactis MG1363 strains containing eg/3, $c b h 2$, and $b g / 1$ gene mixed at proportions of 1:1:1, 2:1:1, 1:2:1, 1:1:2, 1:1:0, 1:0:1, and 0:1:1, separately; SEM, standard error of the means; /, below the detect limitation or without statistical analyses.

Table 3 Fermentative characteristics and microbial compositions of alfalfa before and after ensiling for $140 \mathrm{~d}^{\mathrm{a}}$

a Before ensiling means that alfalfa material is sampled after harvesting from the field for $2 \mathrm{~h}$, and is not fermented in anaerobic silos; After ensiling means that alfalfa material is fermented in anaerobic silo for $140 \mathrm{~d}$ and sampled after silo opened.

b Means in a column without a common superscript letter differ $(P<0.05)$ as analyzed by one-way ANOVA and the Tukey test. cfu, colonyforming units; DM, dry matter; LA/AA, the ratio of lactic acid to acetic acid; $\mathrm{NH}_{3}-\mathrm{N}$, ammonia- $\mathrm{N}$; $\mathrm{N}$, nitrogen; $\mathrm{LAB}$, lactic acid bacteria; FAM, fresh alfalfa material; Control, alfalfa ensiled without treatments; EN, cellulase; LPEN, the combination of Lactobacillus plantarum and cellulase; HT2, HT3, HT4, HT5, E1C1, E1B1, and C1B1, combined engineered Lactococcus lactis subsp. lactis MG1363 strains containing eg/3, $c b h 2$, and $b g / 1$ gene mixed at proportions of 1:1:1, 2:1:1, 1:2:1, 1:1:2, 1:1:0, 1:0:1, and 0:1:1, separately; SEM, standard error of the means; /, no detection.

\section{Figures}




\begin{tabular}{|c|c|c|c|c|c|c|c|c|c|c|c|c|}
\hline \multirow[t]{2}{*}{ Items $^{b}$} & \multirow[t]{2}{*}{$\mathrm{pH}$} & $\begin{array}{l}\text { Lactic } \\
\text { acid }\end{array}$ & $\begin{array}{l}\text { Acetic } \\
\text { acid }\end{array}$ & $\begin{array}{l}\text { Propionic } \\
\text { acid }\end{array}$ & \multirow[t]{2}{*}{$\begin{array}{l}\text { Butyric } \\
\text { acid }\end{array}$} & \multirow[t]{2}{*}{ Alcohol } & \multirow[t]{2}{*}{ LA/AA } & \multirow{2}{*}{$\begin{array}{l}\mathrm{NH}_{3}-\mathrm{N} \\
(\mathrm{g} / \mathrm{kg} \\
\mathrm{N})\end{array}$} & \multirow{2}{*}{$\begin{array}{l}\text { DM } \\
\text { loss } \\
(\%)\end{array}$} & $\begin{array}{l}\text { Aerobic } \\
\text { bacteria }\end{array}$ & LAB & \multirow[t]{2}{*}{$\begin{array}{l}\text { Clostridia } \\
\text { spore }\end{array}$} \\
\hline & & \multicolumn{3}{|c|}{ (g/kg DM) } & & & & & & \multicolumn{2}{|c|}{ (lg cfu/g FM) } & \\
\hline FAM & 6.01 & I & / & / & / & I & / & / & / & 6.97 & 3.40 & 3.54 \\
\hline Control & $5.33^{a}$ & $42.4^{f}$ & $15.7^{a}$ & $0.58^{b}$ & 1.11 & $6.97^{a}$ & $2.70^{\mathrm{e}}$ & $150^{a}$ & $2.14^{a}$ & $6.05^{a}$ & $8.69^{a b}$ & $5.15^{a b}$ \\
\hline EN & $4.86^{b}$ & $58.3^{\mathrm{cd}}$ & $13.6^{a b}$ & $0.00^{c}$ & 1.18 & $3.30^{\mathrm{b}}$ & $4.79^{d}$ & $120^{b}$ & $1.82^{b}$ & $5.74^{a b}$ & $8.24^{a b c}$ & $5.33^{a}$ \\
\hline LPEN & $4.61^{c}$ & $61.5^{c}$ & $8.21^{c}$ & $0.00^{c}$ & 1.31 & $3.00^{b}$ & $7.50^{\mathrm{ab}}$ & $49.3^{d}$ & $1.56^{\mathrm{c}}$ & $5.38^{c d}$ & $7.80^{b c d}$ & $5.16^{a b}$ \\
\hline HT2 & $4.70^{\mathrm{bc}}$ & $72.2^{\mathrm{b}}$ & $10.5^{\mathrm{bc}}$ & $0.00^{c}$ & 1.73 & $3.74^{b}$ & $6.91^{\mathrm{abc}}$ & $75.5^{c}$ & $1.67^{c}$ & $5.18^{c}$ & $8.90^{a}$ & $4.64^{c}$ \\
\hline HT3 & $4.69^{c}$ & $57.2^{\mathrm{cd}}$ & $8.19^{c}$ & $0.42^{b}$ & 1.24 & $2.77^{b}$ & $7.01^{a b c}$ & $58.7^{\mathrm{cd}}$ & $1.56^{\mathrm{c}}$ & $5.56^{b c}$ & $7.20^{d}$ & $4.96^{b}$ \\
\hline HT4 & $4.71^{b c}$ & $79.9^{a}$ & $10.1^{b c}$ & $0.91^{a}$ & 1.64 & $3.41^{b}$ & $7.98^{a}$ & $75.4^{c}$ & $1.56^{c}$ & $5.64^{a b c}$ & $7.84 \mathrm{bcd}$ & $5.25^{a b}$ \\
\hline HT5 & $4.71^{b c}$ & $58.0^{\mathrm{cd}}$ & $9.11^{c}$ & $0.38^{b}$ & 1.60 & $3.08^{b}$ & $6.37^{\mathrm{bc}}$ & $64.6^{\mathrm{cd}}$ & $1.63^{c}$ & $5.62^{a b c}$ & $7.46^{\mathrm{cd}}$ & $5.08^{a b}$ \\
\hline E1C1 & $4.72^{b c}$ & $53.9^{\text {de }}$ & $8.59^{c}$ & $0.00^{c}$ & 1.36 & $2.63^{b}$ & $6.21^{c}$ & $69.3^{c}$ & $1.65^{c}$ & $5.53^{b c}$ & $7.70^{\mathrm{cd}}$ & $5.31^{a}$ \\
\hline E1B1 & $4.74^{b c}$ & $49.9^{e}$ & $7.71^{\mathrm{c}}$ & $0.10 \mathrm{c}$ & 1.35 & $2.67^{b}$ & $6.27^{b c}$ & $66.7^{\mathrm{cd}}$ & $1.61^{c}$ & $5.61^{a b c}$ & $8.32^{a b c}$ & $5.27^{a}$ \\
\hline C1B1 & $4.72^{b c}$ & $52.5^{\text {de }}$ & $8.33^{c}$ & $0.00^{c}$ & 1.37 & $2.67^{b}$ & $6.30^{\mathrm{bc}}$ & $67.8^{c}$ & $1.62^{c}$ & $5.75^{a b}$ & $7.62^{\mathrm{cd}}$ & $5.32^{a}$ \\
\hline SEM & 0.035 & 2.032 & 0.862 & 0.072 & 0.05 & 0.414 & 0.239 & 5.608 & 0.027 & 0.098 & 0.193 & 0.063 \\
\hline $\begin{array}{l}\text { P- } \\
\text { Value }\end{array}$ & $<0.001$ & $<0.001$ & $<0.001$ & $<0.001$ & 0.164 & $<0.001$ & $<0.001$ & $<0.001$ & $<0.001$ & $<0.001$ & $<0.001$ & $<0.001$ \\
\hline
\end{tabular}

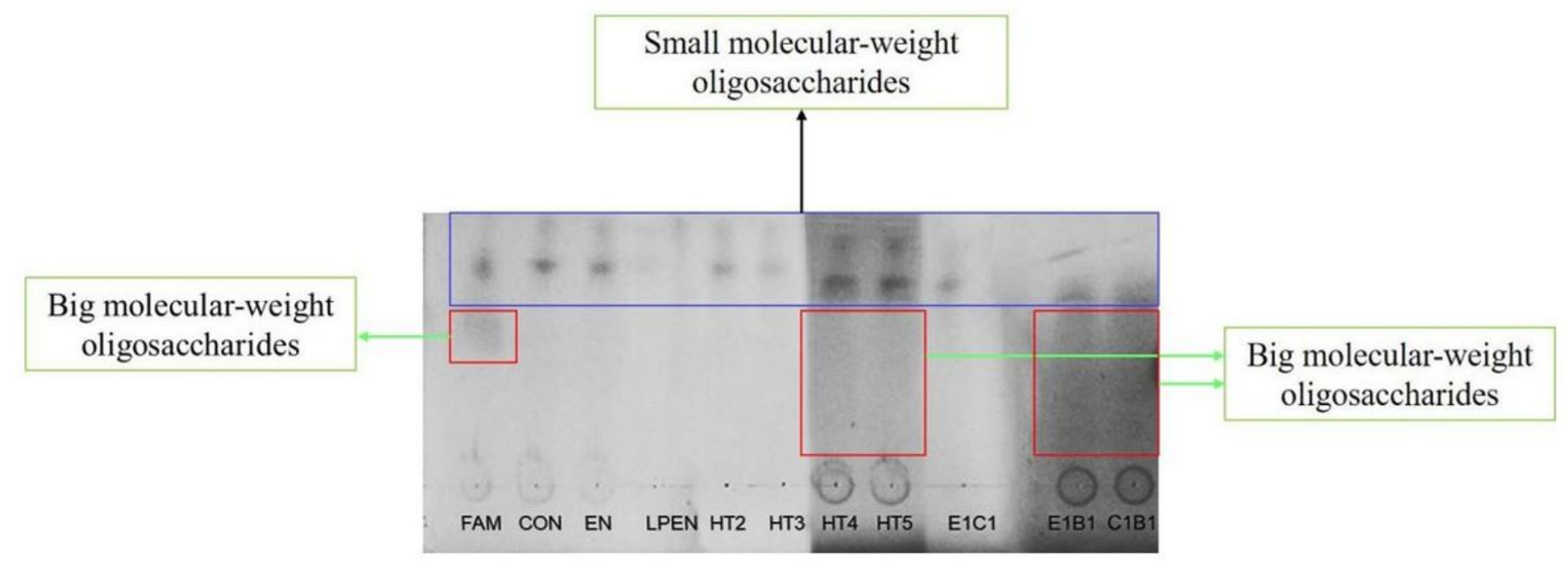

\section{Figure 1}

Thin-layer chromatography testing of oligosaccharide after alfalfa ensiled with treatments for $140 \mathrm{~d}$ FAM, fresh alfalfa material; Control, alfalfa ensiled without treatments; EN, cellulase; LPEN, the combination of Lactobacillus plantarum and cellulase; HT2, HT3, HT4, HT5, E1C1, E1B1, and C1B1, combined engineered Lactococcus lactis subsp. lactis MG1363 strains containing egl3, cbh2, and bgl1 gene mixed at proportions of $1: 1: 1,2: 1: 1,1: 2: 1,1: 1: 2,1: 1: 0,1: 0: 1$, and $0: 1: 1$, separately. 


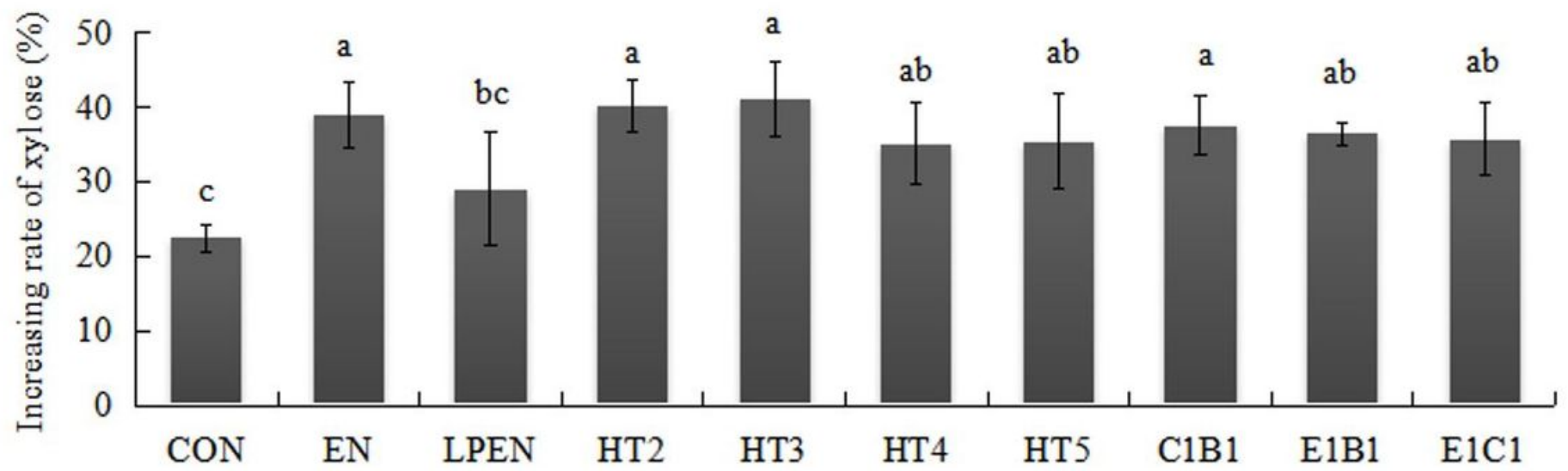

\section{Figure 2}

The effects of treatments on the increasing rate of xylose after ensiling for $140 \mathrm{~d}$. The increasing rate of xylose was calculated by the formula: Increasing rate of $x y l o s e=($ Xylose ensiled alfalfa-Xylose raw alfalfa material $) \div$ Xylose raw alfalfa material $\times 100 \%$. Bars with different letters (a-c) indicated the difference among the treatments at $\mathrm{P}<0.05$ after being analyzed by one-way ANOVA and the Tukey test. CON, alfalfa ensiled without treatments; EN, cellulase; LPEN, the combination of Lactobacillus plantarum and cellulase; HT2, HT3, HT4, HT5, E1C1, E1B1, and C1B1, combined engineered Lactococcus lactis subsp. lactis MG1363 strains containing egl3, cbh2, and bgl1 gene mixed at proportions of 1:1:1, 2:1:1, 1:2:1, 1:1:2, 1:1:0, 1:0:1, and 0:1:1, separately.

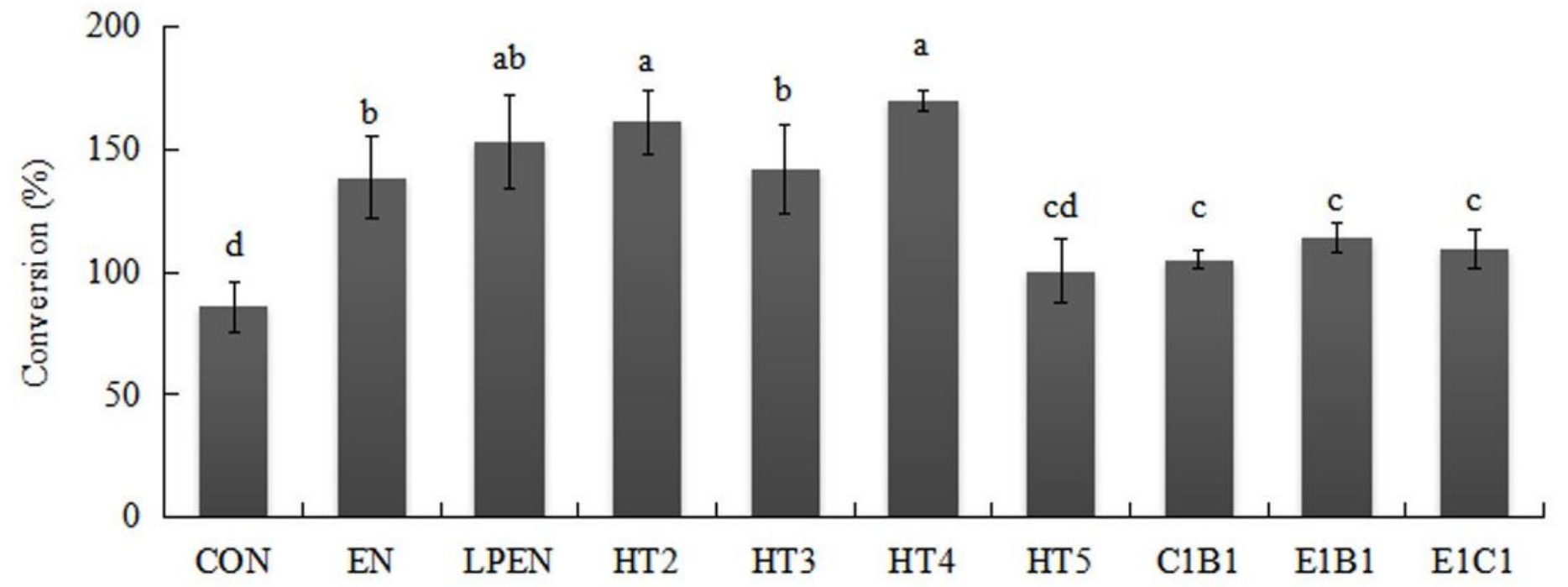

Figure 3

The conversions of water-soluble carbohydrates to lactic acid in ensiled alfalfa. Means in a bar without a common letter differ $(P<0.05)$ from each treatment after being analyzed by one-way ANOVA and the Tukey test. CON, alfalfa ensiled without treatments; EN, cellulase; LPEN, the combination of Lactobacillus plantarum and cellulase; HT2, HT3, HT4, HT5, E1C1, E1B1, and C1B1, combined engineered Lactococcus lactis subsp. lactis MG1363 strains containing egl3, cbh2, and bgl1 gene mixed at proportions of 1:1:1, 2:1:1, 1:2:1, 1:1:2, 1:1:0, 1:0:1, and 0:1:1, separately.

\section{Supplementary Files}

This is a list of supplementary files associated with this preprint. Click to download.

- Graphicabstract.docx 